\title{
Conventional-Microwave Mediated Synthesis and In Vitro Antimicrobial Activity of Novel Carbazole-Efflux Pump Inhibitor Hybrid Antibacterials
}

\author{
Ghazala Yaqub, ${ }^{1}$ Zubi Sadiq, ${ }^{2}$ Almas Hamid, ${ }^{1}$ Amber Fatima, ${ }^{1}$ and Zainab Ijaz \\ ${ }^{1}$ Department of Environmental Sciences, Kinnaird College for Women, Lahore 54000, Pakistan \\ ${ }^{2}$ LCWU, Lahore, Pakistan \\ Correspondence should be addressed to Ghazala Yaqub; ghazala_yaqub@yahoo.com
}

Received 31 March 2017; Accepted 20 August 2017; Published 6 November 2017

Academic Editor: Serkos A. Haroutounian

Copyright (C) 2017 Ghazala Yaqub et al. This is an open access article distributed under the Creative Commons Attribution License, which permits unrestricted use, distribution, and reproduction in any medium, provided the original work is properly cited.

Work presented herein is the first report of two dual-action hybrids synthesized by covalent linkage of carbazole based novel antibacterial compounds with efflux pump inhibitors, that is, indole acetic acid/gallic acid. In this paper, novel antibacterial compounds $\mathbf{2}$ and $\mathbf{3}$ were prepared first and then these were covalently linked with efflux pump inhibitors, that is, indole acetic acid/gallic acid leading to the successful formation of two dual-action hybrids $\mathbf{4}$ and $\mathbf{5}$. Prepared antibacterials and hybrids were evaluated for their bacteria cell killing capability against Escherichia coli, Staphylococcus aureus, Pasteurella multocida, and Bacillus subtilis. Both antibacterial compounds $\mathbf{2}$ and $\mathbf{3}$ were found effective against all tested bacterial strains at different concentrations. But when these compounds were linked with efflux pump inhibitors, they showed dramatic enhancement in their bacterial cell killing potential and minimum inhibitory concentration of all hybrids ranging from $7.250 \mu \mathrm{g} / \mathrm{mL}$ to $0.05 \mu \mathrm{g} / \mathrm{mL}$. These prepared hybrid drugs will be promising and effective new agents in the category of dual-action antibiotics.

\section{Introduction}

Since the past 60 years, antibiotics have been considered critical for the treatment of infectious diseases caused by bacteria and other microbes [1]. One of the major issues that are making antibiotic drug therapy ineffective for the treatment of bacterial infection, thus increasing the mortality rate and public health problem, is resistance developed in bacteria due to these antibiotics [2]. The problem of antibiotic resistance in bacteria emerged due to discriminate use of existing antibiotics by human beings. This led to the development of several modifications in pathogenic bacteria and other disease causing microbes to resist antibiotics and other antimicrobial drugs. There are several mechanisms of bacterial resistance to antibiotics. Using these mechanisms bacteria could chemically alter and inactivate the drugs, render it inactive through physical removal from the cell, or give rise to enzymes that degrade the antibiotics [3]. The most effective mechanism by which a large number of the bacteria resist antibiotics is the physical removal of the antibiotic from the cell using efflux pumps of bacteria. These multidrug efflux pumps in bacteria provide a universal mechanism by which bacteria resist many antibiotics [4]. These efflux pumps can pump antibiotic dose out of the cell using their basic protein shape conformations. Subsequent work showed that almost all antibiotics are subject to efflux pump resistance. Resistance due to these efflux pumps makes several classes of antibiotics, that is, penicillin, cephalosporins, aminoglycosides, macrolides, and tetracyclines, ineffective. Infections caused by multidrug-resistant pathogens play a major role in the morbidity and mortality of hospitalized patients. The increasing resistance to current antibiotic therapies has made the need for discovery of new antimicrobial agents urgent. The rapid spread of bacteria expressing multidrug resistance (MDR) has necessitated the discovery of new antibacterials. Synthesis of novel potent antibiotics effective against MDR bacteria is one of the major aspects of our research project. Efflux pump inhibitors (EPIs) are used to block or deactivate bacterial efflux pumps responsible for the resistance to antibiotics [5]. The most significant aspect of multidrug efflux 
pump inhibition is to reduce the rate of efflux of antibiotics. By controlling the efflux of the antibiotic molecule from the bacterial cells, multidrug efflux pump inhibitors allow greater accumulation of antibiotic molecules in the target bacteria leading to the potentiation of the antibiotic effects. Multidrug efflux pump inhibitors provide a key mechanism to inhibit bacterial resistance and antibiotics; that is, carbazoles play an effective role in bacterial cell death [6]. Thus, there is a need for covalently linking the multidrug efflux pump inhibitor directly to the antibacterial agents. Such compounds have been described as dual-action hybrids. These dual-action compounds represent the hybrid molecules with two separate functions. The presented work was designed to achieve the target of synthesizing the dual-action antibiotics for the treatment of infections caused by drug resistant bacteria. These drugs will be promising and effective new agents in the category of dual-action antibiotics.

\section{Experimental}

2.1. Materials and Methods. All the chemical reagents and solvents exploited for this experimental section were of analytical grade. Analytical TLC was carried out on silica gel precoated $\mathrm{Al}$ based sheets (Merk $60 \mathrm{~F}_{254}, 0.2 \mathrm{~mm}$ thick) using different developing solvents. Spots were visualized under UV-light at 254/365 nm (CAMAG Scientific Inc.). KBr disks were used to record IR spectra on Midac Corporation FTIR spectrophotometer. Proton and carbon NMR spectra were measured on Bruker AXS300 MHz spectrometer using TMS as an internal standard (chemical shift in $\delta, \mathrm{ppm}), \mathrm{U}-$ 2800 Hitachi, UV-VIS. The mass spectrometer was taken by GCMS-QP2010S Shimadzu Scientific Instruments, Inc.

2.2. Synthesis of (E)-2-(1-(6,7,8,9-Tetrahydro-1,3-dinitro-5Hcarbazol-8-yl)ethylideneamino)-3-(1H-imidazol-4-yl)propanoic Acid (2). One mole of compound 1 (303 g) was introduced in a reaction pot having $\mathrm{AcOH}(100 \mathrm{~mL})$ as solvent. An equimolar amount of histidine ( $155 \mathrm{~g}$ ) was added within 15 minutes and refluxed. The reaction progress was monitored by TLC from time to time. The spots under UV-light confirmed the product formation after 3 hours. Cooling conditions furnished the title compound 2.

2.3. Reaction in Microwave. To a mixture of 0.001 moles $(0.303 \mathrm{~g})$ of 6,8 -dinitro-1-acetyl-1,2,3,4-tetrahydro- $9 H$-carbazole in minimum amount of acetic acid $(2 \mathrm{~mL}), 0.001$ moles $(0.155 \mathrm{~g})$ of histidine were added. The reaction mixture was irradiated in microwave at the power level of 100 Watt. Reaction progress was monitored by TLC until its completion in 60 seconds. The contents of the reaction mixture as product $\mathbf{2}$ were air dried and recrystallized from methanol to obtain $\mathbf{2}$ in considerable yield.

$\mathrm{UV} \lambda_{\max }(\mathrm{MeOH}): 261,295,340,395 \mathrm{~nm}$. IR (KBr, $v_{\text {max. }}$ $\left.\mathrm{cm}^{-1}\right): 1417\left(\mathrm{NO}_{2}\right), 1633(\mathrm{C}=\mathrm{N}), 1705(\mathrm{C}=\mathrm{O}), 2925(\mathrm{OH}), 2980$ (CH aliphatic), 3036 (aromatic ring), $3405(\mathrm{NH}) .{ }^{1} \mathrm{H}-\mathrm{NMR}$ $(\delta): 7.45$ (s, 1H, CH-N), 6.82 (s, 1H, CH-NH), 13.01 (s, 1H, NH$\mathrm{CH}), 11.5(\mathrm{~s}, 1 \mathrm{H}, \mathrm{OH}), 1.8\left(\mathrm{~s}, 3 \mathrm{H}, \mathrm{CH}_{3}\right), 2.3(\mathrm{t}, 1 \mathrm{H}), 1.8-1.9(\mathrm{~m}$, $2 \mathrm{H}, 2 \mathrm{CH}_{2}$ cyclo), 2.14 (t, 2H), 8.3 (s. $1 \mathrm{H}, \mathrm{Ar}-\mathrm{H}$ ), 9.01 (s. $1 \mathrm{H}$, Ar-H), 10.29 (s, $1 \mathrm{H}, \mathrm{NH}) .{ }^{13} \mathrm{C}-\mathrm{NMR}(\delta): 14.7,21.5,25.6,26.3$,
38.3, 38.8, 67.2, 108.5, 109.9, 121.5, 129.3, 131.3, 133.7, 135.7, 137.6, 142.6, 177.8. For $\mathrm{C}_{19} \mathrm{H}_{19} \mathrm{~N}_{5} \mathrm{OS}$, calculated: C 54.54, H 4.58, N 19.08, O 21.80. found, C 54.53, H 4.60, N 19.07, O 21.82. MS $\left(\mathrm{ES}^{+}\right): 440\left(\mathrm{MH}^{+}\right)$.

2.4. Synthesis of (Z)-N1-(1-(6,7,8,9-Tetrahydro-1,3-dinitro-5Hcarbazol-8-yl)ethylidene)ethanedithioamide (3). 6,8-Dinitro1-acetyl-1,2,3,4-tetrahydro- $9 H$-carbazole 1 (0.1 mol, $30.3 \mathrm{~g})$ dissolved in glacial acetic acid $(40 \mathrm{~mL})$ refluxed with rubeanic acid $(0.1 \mathrm{~mol}, 12 \mathrm{~g})$ for 3.5 hours, as inspected by TLC. The same workup conditions were applied as for compound $\mathbf{2}$ to attain the desired product 3 .

2.5. Reaction in Microwave. Compound 1 (0.303 g, $1 \mathrm{mmol})$ was acidified with a minimum amount of acetic acid $(2 \mathrm{~mL})$ and activated under microwaves for 5 seconds. After this, rubeanic acid $(0.120 \mathrm{~g}, 1 \mathrm{mmol})$ was added and the reaction mixture was checked by TLC after equal irradiation time. The product started to appear after 30 seconds but it was obvious at 1 minute and even more intense at 1.5 minutes. After workup, product 3 was obtained.

$\mathrm{UV} \lambda_{\max }(\mathrm{MeOH}): 268,299,378 \mathrm{~nm}$. IR $\left(\mathrm{KBr}, v_{\max } \mathrm{cm}^{-1}\right)$ : $1416\left(\mathrm{NO}_{2}\right), 1635(\mathrm{C}=\mathrm{N}), 1709(\mathrm{C}=\mathrm{O}), 2930(\mathrm{OH}), 3036$ (aromatic ring), $3405(\mathrm{NH}) .{ }^{1} \mathrm{H}-\mathrm{NMR}(\delta): 3.6\left(\mathrm{~s}, 2 \mathrm{H}, \mathrm{NH}_{2}\right.$; exchangeable), $2.5\left(\mathrm{~s}, 3 \mathrm{H}, \mathrm{CH}_{3}\right), 2.81(\mathrm{t}, 1 \mathrm{H}), 1.82-1.93(\mathrm{~m}$, $2 \mathrm{H}, 2 \mathrm{CH}_{2}$ cyclo), 2.19 (t, $2 \mathrm{H}$ ), 8.13 (s. $1 \mathrm{H}, \mathrm{Ar}-\mathrm{H}$ ), 8.41 (s. $1 \mathrm{H}$, Ar-H), 10.13 (s, $1 \mathrm{H}, \mathrm{NH}) .{ }^{13} \mathrm{C}-\mathrm{NMR}(\delta): 20.5,21.9,25.4,26.1$, 108.3, 109.9, 121.5, 129.3, 131.3, 137.6, 142.7, 164.8, 190.3, 232.2. For $\mathrm{C}_{19} \mathrm{H}_{19} \mathrm{~N}_{5} \mathrm{OS}$, calculated: C 47.40, H 3.73, N 17.27, O 15.78, $\mathrm{S}$ 15.82. C 47.39, H 3.72, N 17.29, O 15.80, S $15.82 \mathrm{MS}\left(\mathrm{ES}^{+}\right)$: $405.1\left(\mathrm{MH}^{+}\right)$.

2.6. Synthesis of Histidine Substituted Imine of 6,7,8,9Tetrahydro-1,3-dinitro-5H-carbazole with Gallic Acid (HYBRID 4). Compound 2 ( $1 \mathrm{mmol}, 0.440 \mathrm{~g}$ ) was stirred in dry DMF, while the equimolar quantity of gallic acid $(0.170 \mathrm{~g})$ was introduced with small intervals. The reaction was speeded up when concentrated sulphuric acid was added to reaction flask. When the reaction mixture was dropped to room temperature, it was refluxed for 3.45 hours. After that, the contents of the flask were executed at room temperature. To the reaction mixture, EtOAc and water were added. Ethyl acetate layer was separated and hybrid 4 was achieved when it dried. In another method of workup, sodium bicarbonate solution was added until effervescence ceased. Dichloromethane was used to quench the product in separating funnel. The aqueous layer was washed with a small quantity of DCM to enhance the amount of product. The lower organic layer was dried over anhydrous sodium sulfate and concentrated on rotary evaporator. Yellowish oily product as hybrid $\mathbf{4}$ has the same Rf value as for EtOAc layer.

2.7. Reaction in Microwave. Compound 2 ( $0.001 \mathrm{~mol}, 0.440 \mathrm{~g})$ was irradiated in dry DMF $(1.5 \mathrm{~mL})$, while the equimolar quantity of gallic acid $(0.170 \mathrm{~g})$ was introduced into reaction pot with a few drops of concentrated sulphuric acid. It was irradiated for 30 seconds and then went for workup as mentioned in its conventional way. Compound $\mathbf{4}$ was obtained in good yield. 


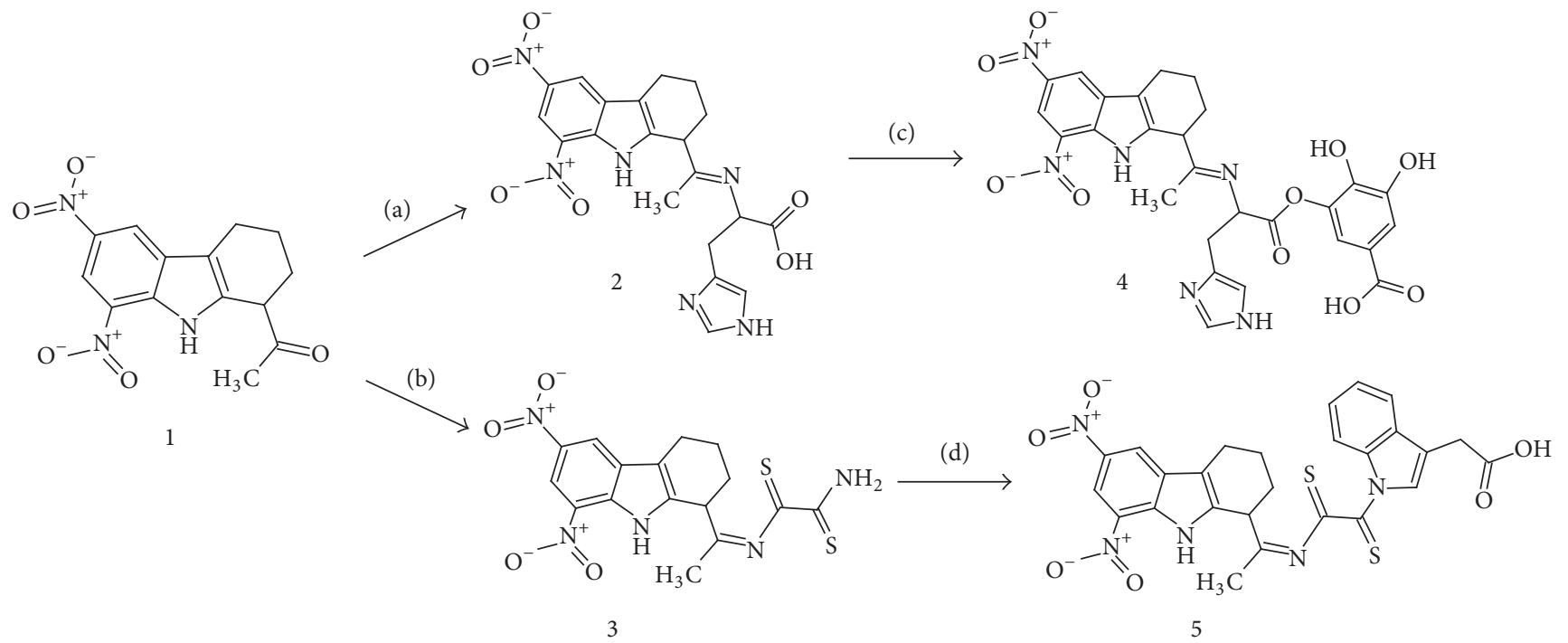

Scheme 1: Synthesis of potential antibiotic compounds 2-5. (a) Histidine, (b) rubeanic acid, (c) indole-3-acetic acid, and (d) gallic acid.

$\mathrm{UV} \lambda_{\max }(\mathrm{MeOH}): 270,345,389,395 \mathrm{~nm} . \mathrm{IR}\left(\mathrm{KBr}, v_{\max }\right.$ $\left.\mathrm{cm}^{-1}\right): 1417\left(\mathrm{NO}_{2}\right), 1637(\mathrm{C}=\mathrm{N}), 1236(\mathrm{C}-\mathrm{O}), 1720(\mathrm{C}=\mathrm{O}), 2927$ $(\mathrm{OH}), 2985$ (CH aliphatic), 3035 (aromatic ring), $3405(\mathrm{NH})$. ${ }^{1} \mathrm{H}-\mathrm{NMR}(\delta): 11.01$ (s, 1H, OH; exchangeable), $5.14(\mathrm{~s}, 1 \mathrm{H}$, $2 \mathrm{OH}$ ), 7.45 (s, 1H, Ar-H), 7.32 (s, 1H, Ar-H), 3.23 (s, 2H, $\mathrm{CH}_{2}$ ), 7.29 (s, 1H, CH-N), 6.95 (s, 1H, CH-NH), 12.05 (s, 1H, NH$\mathrm{CH})$ remaining were same as $2 .{ }^{13} \mathrm{C}-\mathrm{NMR}(\delta): 14.7,21.9,25.4$, $26.5,38.5,38.9,64.6,69.2,108.5,109.9,114.6,115.7,119.9,121.9$, $124.5,129.9,131.4,131.9,133.8,135.7,137.6,141.8,142.7,146.7$, 147.8, 164.6. For $\mathrm{C}_{19} \mathrm{H}_{19} \mathrm{~N}_{5} \mathrm{OS}$, Calculated: C 54.73, $\mathrm{H} 4.08$, $\mathrm{N} 14.18$, O 27.00. found: C 54.74, H 4.08, N 14.17, O 27.02. MS $\left(\mathrm{ES}^{+}\right): 592.0\left(\mathrm{MH}^{+}\right)$.

2.8. Synthesis of 2-(1-(Amino(Z)-(thioformyl)-N-(1-(6,7,8,9tetrahydro-1,3-dinitro-5H-carbazol-8-yl)ethylidene)methanethiocarbamoyl)-1H-indol-3-yl)acetic Acid (HYBRID 5). Compound 3 ( $1 \mathrm{mmol}, 0.405 \mathrm{~g})$, sodium acetate $(1 \mathrm{mmol}$, $0.082 \mathrm{~g})$, and indole- 3 -acetic acid $(0.175 \mathrm{~g}, 1 \mathrm{mmol})$ were refluxed for 3.5 hours in methanol $(5 \mathrm{~mL})$. After that contents of the flask were poured into crushed ice and then filtered. The filtrate as mentioned by TLC showed the formation of hybrid 5 which was freeze-dried to obtain 5 in solid form.

2.9. Reaction in Microwave. Compound 6 ( $1 \mathrm{mmol}, 0.405 \mathrm{~g}$ ), sodium acetate ( $1 \mathrm{mmol}, 0.082 \mathrm{~g}$ ), and indol-3-acetic acid $(0.175 \mathrm{~g}, 1 \mathrm{mmol})$ was irradiated for 5 seconds in methanol $(1.5 \mathrm{~mL})$. After that contents of the flask were poured into crushed ice and then filtered. The filtrate as mentioned by TLC showed the formation of hybrid 5 which was freezedried to obtain $\mathbf{5}$ in solid form which was further recrystallized in methanol for purity.

UV $\lambda_{\max }(\mathrm{MeOH}): 290,339,380,399 \mathrm{~nm}$. IR (KBr, $v_{\max }$ $\left.\mathrm{cm}^{-1}\right): 1418\left(\mathrm{NO}_{2}\right), 1634(\mathrm{C}=\mathrm{N}), 1348(\mathrm{C}=\mathrm{S}), 1712(\mathrm{C}=\mathrm{O}), 2933$ $(\mathrm{OH}), 3036$ (aromatic ring) $3445(\mathrm{NH}) .{ }^{1} \mathrm{H}-\mathrm{NMR}(\delta): 11.2$ (s, 1H, OH), 3.28 (s, 2H, $\mathrm{CH}_{2}$ ), 6.45 (s, 1H, Ar-H), 7.67-8.05 $(\mathrm{m}, 4 \mathrm{H}, \mathrm{Ar}-\mathrm{H})$ remaining signals were similar to parent compound. ${ }^{13} \mathrm{C}-\mathrm{NMR}(\delta): 14.4,21.9,25.4,26.9,38.5,42.7$,
108.6, 109.6, 109.9, 111.3, 119.2, 120.4, 121.9, 122.4, 127.8, 129.3, $129.8,131.3,131.7,136.7,137.6,142.7,164.8,174.6,232.2$. For $\mathrm{C}_{19} \mathrm{H}_{19} \mathrm{~N}_{5} \mathrm{OS}$, Calculated: C 57.80, H 4.07, N 13.48, O 18.48, S 6.17. found C 57.80, H 4.06, N 13.50, O 18.49, S 6.19. MS (ES $\left.{ }^{+}\right)$: $606.0\left(\mathrm{MH}^{+}\right)$.

\section{Pharmacological Evaluation: Antimicrobial Assay}

The in vitro antimicrobial appraisal was performed by agar well dilution method [6]. The specification of the instruments used for this activity is as follows: Muller Hinton agar (Scharlau Chemie, 1-136), laminar flow cabinet local, made by Technico scientific supplier (blower, fluorescent, and UV-light), incubator (Ehret, BK4444), autoclave (Hirayama, HVA-110, maximum pressure $=4$ bar), refrigerator (capacity $14 \mathrm{CFt}$, Model 9188 MDS, Dawlance), and microwave oven (capacity 43 liters, Model 55-APB-9, Orient). Clinically important four bacterial strains as Escherichia coli, Staphylococcus aureus, Pasteurella multocida, and Bacillus subtilis were selected. The minimum active concentration of compounds was variable according to the antimicrobial strains. Antibacterial activities were done by standard agar well diffusion method [6].

\section{Results and Discussion}

The work presented herein is the very first report of the synthesis of carbazole-Indole acetic acid and gallic acid based dual-action hybrids. In this work, some novel potential antibiotics were synthesized first and then these antibiotics were covalently linked with efflux pump inhibitor, that is, indole acetic acid to prepare dual-action hybrids, that is, 4 and 5 (Scheme 1). Both antibacterial compounds and dualaction hybrids were prepared via microwave mediated synthesis along with conventional synthetic routes. The prepared dual-action hybrids are capable of performing two separate functions as one molecule: that is, one part plays a role as 
TABLE 1: Physical characteristics of compounds 1-5.

\begin{tabular}{|c|c|c|c|c|c|}
\hline \multirow{2}{*}{ Compound } & \multicolumn{2}{|c|}{ Yield (\%) } & \multirow{2}{*}{ Mol. formula } & \multirow{2}{*}{$\begin{array}{l}\text { Conventional reflux time } \\
\text { (h) }\end{array}$} & \multirow{2}{*}{$\begin{array}{l}\mu \mathrm{w} \text { irradiation } \\
\quad(\mathrm{sec})\end{array}$} \\
\hline & Conventional & $\mu \mathrm{w}$ & & & \\
\hline 1 & 74 & 85 & $\mathrm{C}_{14} \mathrm{H}_{13} \mathrm{~N}_{3} \mathrm{O}_{5}$ & 3.5 & 780 \\
\hline 2 & 34 & 58 & $\mathrm{C}_{20} \mathrm{H}_{20} \mathrm{~N}_{6} \mathrm{O}_{6}$ & 3 & 60 \\
\hline 3 & 79 & 80 & $\mathrm{C}_{16} \mathrm{H}_{15} \mathrm{~N}_{5} \mathrm{O}_{4} \mathrm{~S}_{2}$ & 3.5 & 90 \\
\hline 4 & 75 & 83 & $\mathrm{C}_{27} \mathrm{H}_{22} \mathrm{~N}_{6} \mathrm{O}_{7} \mathrm{~S}_{2}$ & 3.5 & 5 \\
\hline 5 & 70 & 81 & $\mathrm{C}_{27} \mathrm{H}_{24} \mathrm{~N}_{6} \mathrm{O}_{10}$ & 3.45 & 30 \\
\hline
\end{tabular}

TABLE 2: Minimum inhibitory concentrations of synthesized compounds 2-5.

\begin{tabular}{lcccc}
\hline \multirow{2}{*}{ Compounds } & & \multicolumn{4}{c}{ MIC in $\mu \mathrm{g} / \mathrm{mL}$} \\
& Escherichia coli & Staphylococcus aureus & Pasteurella multocida & Bacillus subtilis \\
\hline $\mathbf{2}$ & 7.250 & 58 & 3.625 & 117 \\
$\mathbf{3}$ & 58 & 117 & 1870 & 0.453 \\
$\mathbf{4}$ & 0.453 & 7.250 & 0.453 & 0.906 \\
$\mathbf{5}$ & 1.812 & 7.250 & 0.056 & \\
\hline
\end{tabular}

antibiotic, while the other part acts as efflux pump inhibitor. Previous studies also successfully report and support the idea of promising strategy for combating bacterial drug resistance arising from multidrug-resistance efflux pumps [7] by developing covalent linkage between efflux pump inhibitor and antibacterial agent that is normally a pump substrate $[8,9]$.

Firstly we have synthesized some antibacterial compounds, that is, $\mathbf{2}$ and $\mathbf{3}$, out of which compounds $\mathbf{2}$ and $\mathbf{3}$ reacted with gallic acid and indole acetic acid, well-known efflux pump inhibitors, to get dual-action hybrids $\mathbf{4}$ and $\mathbf{5}$. Compound 1 was previously prepared and fully characterized by reaction of 6,7,8,9-tetrahydro-1,3-dinitro-5 $\mathrm{H}$-carbazole with acetylchloride in acidic media. It took only 13 minutes in preparation of product 1 in the microwave (synthetic method of compound 1 was already reported in our filed patent, 2016). Compound 1 was found extremely reactive towards histidine and rubeanic acid resulted in the formation of very effective antibacterial compounds 2 and 3, respectively. Compounds $\mathbf{2}$ and $\mathbf{3}$ were also synthesized using the green technology of microwave and it took 60 seconds and 1.5 minutes, respectively, in their formation. 2 and $\mathbf{3}$ were found to be very good antibacterial compounds (as their pharmacological studies revealed). The compounds 2 and 3 reacted with gallic acid and indole acetic acid, effective efflux pump inhibitors, to prepare two carbazole-efflux pump inhibitor based dualaction hybrids, that is, 4 and 5 (Scheme 1). Reaction methodology in microwave utilizes molecular excitation due to electromagnetic radiation. Enormous acceleration at ambient pressure is a driving force that reduces time requirement from hours to seconds. All the conventionally synthesized compounds $\mathbf{4}$ and $\mathbf{5}$ were successfully synthesized in the microwave using its protocols. The ratio of reagents remained the same but there was significant lessening of solvents in this approach. Their time requirement and yield were summarized in Table 1. Previous studies support the fact that dual-action hybrid antibacterials of this type carry the potential advantage of synchronous and equimolar delivery of an antibacterial and an efflux pump inhibitor successfully to sites of infection [10] and may be capable of slowing down the onset of resistance since they challenge bacteria to acquire resistance phenotypes at two independent targets [11].

The synthesized dual-action hybrids (4-5) can perform two functions as one molecule; that is, one part acts as antibacterial agent, while the other part acts as efflux pump inhibitor which will block the bacterial efflux pumps; thus, bacteria will no more be able to efflux the antibiotic outside and antibiotic will be in better position to kill bacterial cell. Both dual-action hybrids showed very good MIC against tested bacterial strains, that is, Escherichia coli, Staphylococcus aureus, Pasteurella multocida, and Bacillus subtilis (Table 2).

MIC of compound 2 against Escherichia coli, Staphylococcus aureus, Pasteurella multocida, and Bacillus subtilis was found to be $7.250,58,3.625$, and $117 \mu \mathrm{g} / \mathrm{mL}$, respectively, which was improved to $0.453,7.250,0.453$, and 0.453 when it remained linked with efflux pump inhibitor to form hybrid compound 4. Minimum inhibitory concentration of compound 3 against tested bacterial strains was found to be $58,117,1870$, and $1.812 \mu \mathrm{g} / \mathrm{mL}$, respectively, which was enhanced to $1.812,7.250,0.056$, and $0.906 \mu \mathrm{g} / \mathrm{mL}$ when it was treated with efflux pump inhibitor, that is, indole acetic acid forming hybrid compound 5.

\section{Conclusions}

This work is the very first report of carbazole-efflux pump inhibitor based dual-action hybrid. Successful formation of the hybrid compounds $\mathbf{4}$ and $\mathbf{5}$ opens new pathways for future endeavors. Production of novel antibacterial compounds (2 and 3) first with good antibacterial activity and then linking these antibacterials with efflux pump inhibitors to synthesize hybrids provided the key mechanism to antibiotics to 
overcome the resistance of bacteria against antibiotic and the ability of hybrids to act as antibiotics was also enhanced.

\section{Conflicts of Interest}

The authors declare that they do not have any conflicts of interest regarding the publication of this manuscript or the funding received to complete this project.

\section{Acknowledgments}

The authors would like to acknowledge Higher Education Commission of Pakistan for funding the project and Kinnaird College for Women, Lahore, for providing necessary facilities.

\section{References}

[1] A. J. Alanis, "Resistance to antibiotics: are we in the post-antibiotic era?" Archives of Medical Research, vol. 36, no. 6, pp. 697$705,2005$.

[2] K. Cheol-In, K. Sung-Han, B. P. Wan et al., "Bloodstream infections caused by antibiotic-resistant gram-negative bacilli: risk factors for mortality and impact of inappropriate initial antimicrobial therapy on outcome," Antimicrobial Agents and Chemotherapy, vol. 49, no. 2, pp. 760-766, 2005.

[3] F. C. Tenover, "Mechanisms of antimicrobial resistance in bacteria," The American Journal of Medicine, vol. 119, no. 6, supplement 1, pp. S3-S10, 2006.

[4] A. M. A. Webber and L. J. V. Piddock, "The importance of efflux pumps in bacterial antibiotic resistance," Journal of Antimicrobial Chemotherapy, vol. 5, no. 1, pp. 9-11, 2002.

[5] A. Momen, M. Walid, A. Turki, and T. Ibrahim, "Efflux pump inhibitors (EPIs) as new antimicrobial agents against Pseudomonas aeruginosa," Libyan Journal of Medicine, vol. 6, article 5870, 2011.

[6] G. Yaqub, H. Abdul, U. Muhammad, A. Erum, and M. Bushra, "In vitro antifungal and antibacterial activity of carbazoles", Asian Journal of Chemistry, vol. 24, no. 10, pp. 5121-5123, 2012.

[7] G. Yaqub, Z. Sadiq, A. Hamid, and S. Iqbal, "Very first synthesis of carbazole conjugates with efflux pump inhibitor as dual action hybrids," World Academy of Science, Engineering and Technology, International Science Index, Chemical and Molecular Engineering, vol. 1, no. 12, article 256, 2014.

[8] A. R. Ball, G. Casadei, S. Samosorn et al., "Conjugating berberine to a multidrug resistance pump inhibitor creates an effective antimicrobial," ACS Chemical Biology, vol. 1, no. 9, pp. 594-600, 2006.

[9] N. German, P. Wei, G. W. Kaatz, and R. J. Kerns, "Synthesis and evaluation of fluoroquinolone derivatives as substrate-based inhibitors of bacterial efflux pumps," European Journal of Medicinal Chemistry, vol. 43, no. 11, pp. 2453-2463, 2008.

[10] M. R. Barbachyn, "Recent advances in the discovery of hybrid antibacterial agents," in Annual Reports in Medicinal Chemistry, J. E. Macor, Ed., vol. 43 of Annual Reports in Medicinal Chemistry, pp. 281-290, Elsevier Academic Press, San Diego, Calif, USA, 2008.

[11] P. S. Charifson, A.-L. Grillot, T. H. Grossman et al., "Novel dual-targeting benzimidazole urea inhibitors of DNA gyrase and topoisomerase IV possessing potent antibacterial activity: Intelligent design and evolution through the judicious use of structure-guided design and stucture-activity relationships," Journal of Medicinal Chemistry, vol. 51, no. 17, pp. 5243-5263, 2008. 

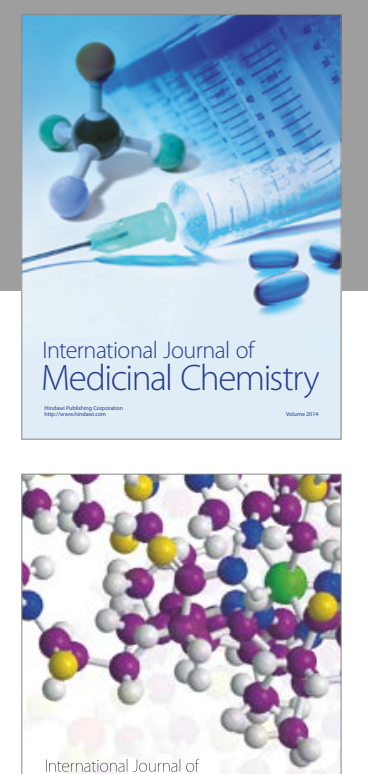

Carbohydrate Chemistry

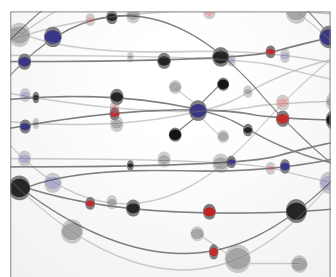

The Scientific World Journal
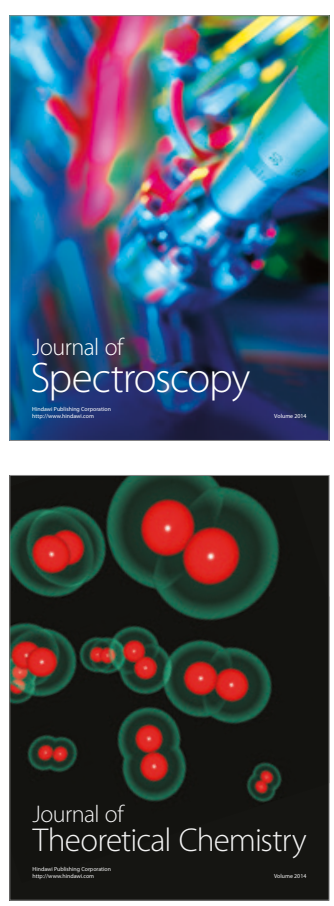
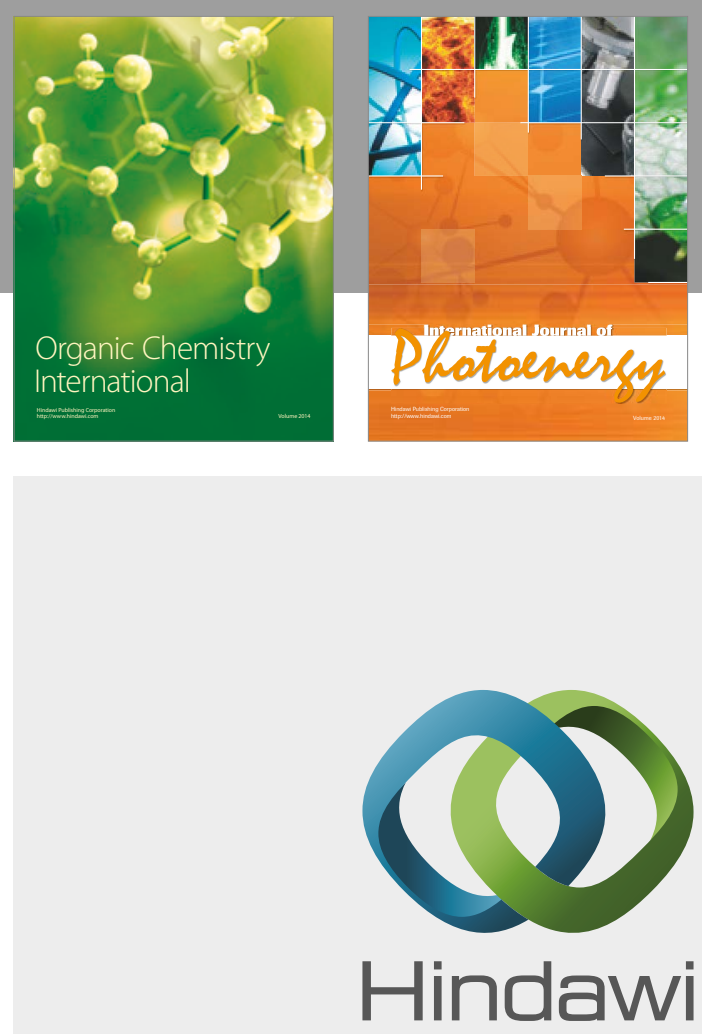

Submit your manuscripts at

https://www.hindawi.com

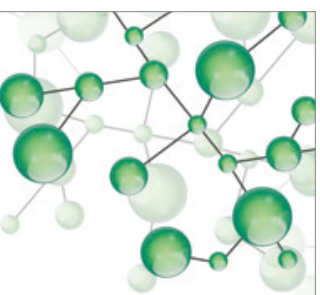

International Journal of

Inorganic Chemistry

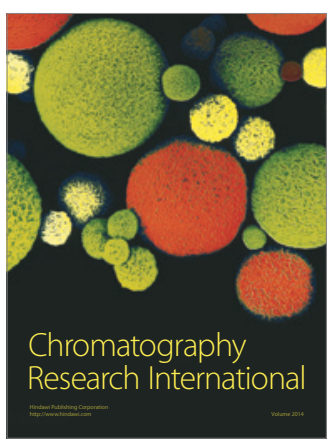

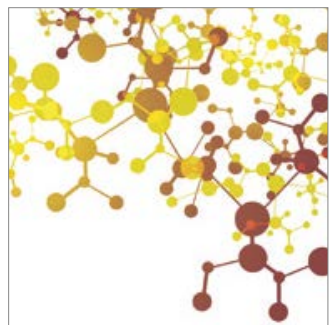

Applied Chemistry
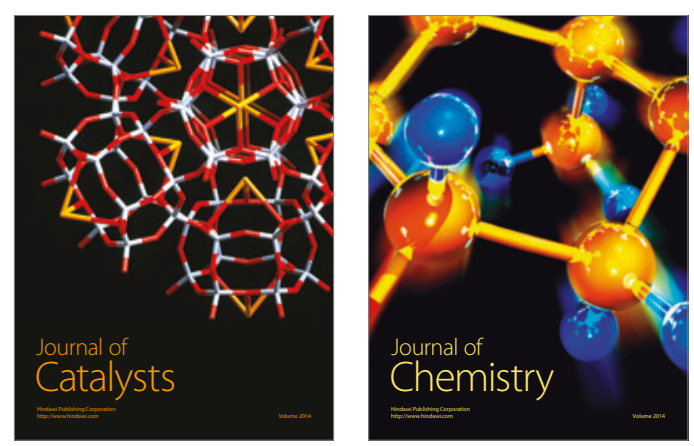
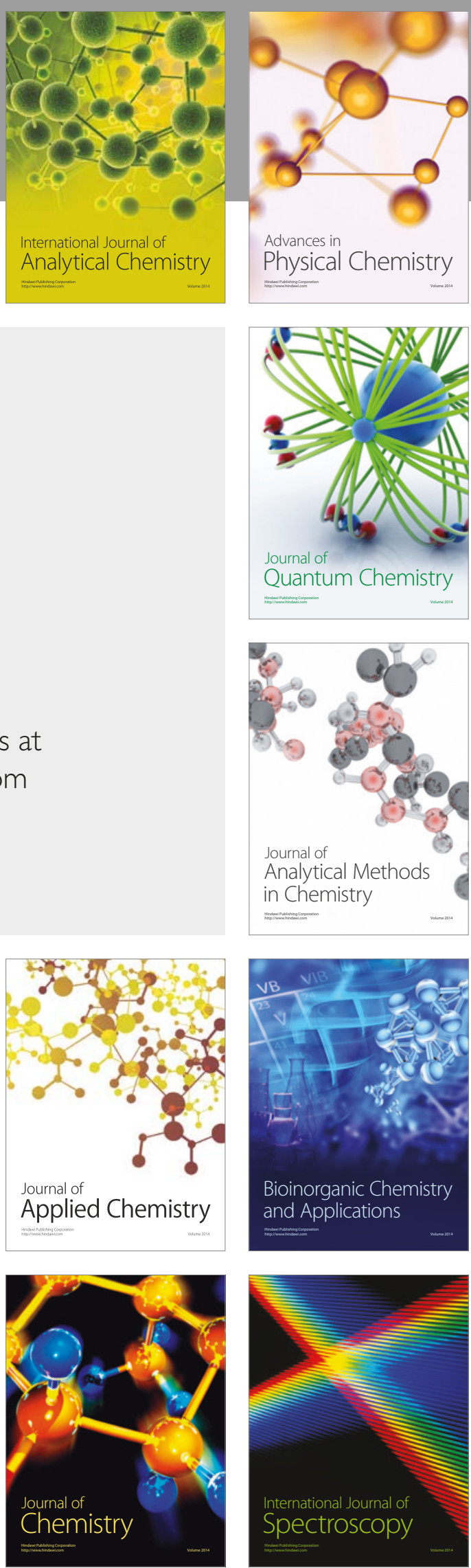